\title{
Pengaruh Karakteristik Individu Terhadap Motivasi Pegawai Pada Dinas Kesehatan Provinsi Jambi
}

\author{
Said Almaududi, Muhammad Emil \\ Fakultas Ekonomi, Universitas Batanghari Jambi, Indonesia \\ Correspondence email: saidalmaududi@yahoo.com
}

\begin{abstract}
The research aims to find out how the characteristics of individual to motivation in jambi province health service is partially over the period 2013-2017. The object of this analysis of health services the province of Jambi. The sample used in this study is as much as 79 (seventy-nine) employees of the health services the province of Jambi. Jambi Province health service is one of the agencies that play a role in implementing health development. Health services have the task of carrying out some local Government Affairs based on the principle of autonomy in health development in jambi province. The method used is descriptive quantitative methods with the individual characteristics of the independent variable, while the dependent variable is the motivation. Analysis tools used are simple linear regression, t-test, the coefficient of determination. Based on the results of the regression analysis abowed that the regression equation $Y=1.648+0.506+e$, with $R^{2} 0.388$. This means that the characteristics of the individual employee motivation significantly to influential on health service Office of the province of jambi, with value of 6.992 and significant levels 0.000. In this study, the author gives advice to the Office, that Office should health services strengthening employee motivation Jambi province so that raises a better employee performance again.
\end{abstract}

Keywords: individual Characteristics and motivation

\section{PENDAHULUAN}

Sumber daya manusia di dalam suatu organisasi memegang peranan utama yang berpengaruh pada setiap kegiatan-kegiatan yang dilakukan oleh organisasi dan dianggap sebagai ujung tombak untuk menjalankan aktivitas organisasi sehari-hari. Sumber daya manusia merupakan faktor yang sangat penting bahkan tidak dapat di lepaskan dari sebuah organisasi atau lembaga dalam mencapai tujuan. Kegiatan operasional sebuah organisasi tentunya tidak dapat terlepas dari peran manusia sebagai penggerak. Manusia merupakan aset yang penting bagi instansi dan keberadaannya sangat dibutuhkan. Keberadaan manusia merupakan sumber daya yang paling istimewa, keistimewaan yang ada pada manusia adalah satu-satunya sumber daya di dalam instansi yang mempunyai pikiran, perasaan dan kepribadian yang berbeda-beda menjadikan pegawai mempunyai ciri khas tersendiri yang mampu membentuk suatu karakteristik individu pada pegawai. Baik dan buruknya karakteristik individu pegawai tergantung pada bagaimana mereka menerapkannya.

Setiap manusia memiliki karakteristik individu yang berbeda antara satu dengan yang lainnya, tidak mudah bagi seorang individu menghasilkan karya yang sama dengan individu lain namun setiap individu tersebut tetap berusaha untuk menghasilkan yang terbaik. Terkait dengan karakteristik individu antara lain yaitu faktor-faktor yang mudah didefenisikan dan tersedia, data yang dapat diperoleh sebagian besar dari informasi yang tersedia dalam berkas personalia seorang pegawai. Menurut Robbins \& Judge (2008) Karakteristik individu merupakan karakteristik perseorangan seperti usia, gender, ras dan masa kerja (Jabatan) yang diperoleh secara mudah dan objektif dari arsip pribadi seseorang. Undang-undang No. 43 tahun 1999 tentang kepegawaian, dimana pegawai negeri sipil merupakan aparatur negara. Dalam rangka pencapaian tujuan pembangunan nasional dan penyelenggaraan tugas-tugas pemerintahan diperlukan pegawai yang memiliki kemampuan untuk melaksanakan volume kerja yang sudah dibebankan kepada pegawai negeri sipil tersebut dilingkungan kerja dan pemerintah menjadi penyelenggara adalah merupakan orang yang terlihat langsung dalam penyelenggaraan tugas-tugas pemerintah dan pelaksanaan pembangunan hendaklah dapat memberikan perhatian yang serius terhadap pegawai negeri sipil yang berada dalam lembaga atau instansi yang dipimpinnya.

Pegawai negeri sipil perlu mendapatkan perhatian dari pemerintah, karena pegawai negeri sipil adalah merupakan perpanjangan tangan dari pemerintahan dan pembangunan di tengah-tengah masyarakat sesuai dengan visi dan misi pegawai negeri sipil itu sendiri, yaitu memberikan pelayanan kepada 
masyarakat, setia dan terus bekerja. Pelaksanaan tugas dan pekerjaan merupakan suatu kewajiban bagi para pegawai negeri sipil di dalam suatu organisasi. Dalam pelaksanaan tugas dan pekerjaan tersebut terdapat suatu tujuan yang sama yakni mengharapkan suatu hasil yang baik serta memuaskan sesuai dengan apa yang telah di tentukan sebelumnya. Untuk mendapatkan suatu hasil kerja yang baik dan sesuai dengan tujuan organisasi maka setiap pegawai negeri sipil mempunyai suatu aturan yang dituangkan dalam bentuk kebijakan. Kebijakan ini dibuat dengan maksud agar setiap komponen pegawai negeri sipil melaksanakan tugas sesuai dengan tujuan yang telah ditetapkan. Begitu juga pegawai di instansi bagian Dinas Kesehatan Provinsi Jambi mempunyai tugas melaksanakan sebagian urusan pemerintah daerah berdasarkan azas otonomi dan tugas pembantuan dibidang kesehatan.

Menurut Mulyadi (2015) Motivasi adalah dorongan dasar yang menggerakkan seseorang bertingkah laku. Sebuah instansi dalam upaya meningkatkan serta mempertahankan motivasi pegawai yang tinggi pada setiap pegawai diperlukan untuk menunjang pencapaian tujuan Dinas Kesehatan Provinsi Jambi. Karakteristik individu harus menjadi perhatian penting, karena dengan adanya pemahaman akan karakteristik individu diharapkan motivasi pegawai akan meningkat. Tujuan penelitian ini adalah untuk mengetahui karakteristik individu dan motivasi pegawai pada Dinas Kesehatan Provinsi Jambi dan untuk mengetahui pengaruh karakteristik individu terhadap motivasi pegawai pada Dinas Kesehatan Provinsi Jambi.

\section{Tinjauan Pustaka \\ Manajemen}

Manajemen Menurut Sedarmayanti (2009) Manajemen adalah fungsi yang berhubungan dengan upaya mewujudkan hasil tertentu kegiatan orang lain. Menurut Adisetiawan (2013) Manajemen adalah ilmu dan seni yang mengatur proses pemanfaatan sumber daya manusia dan sumber-sumber lainnya secara efektif dan efisien untuk mencapai suatu tujuan tertentu. Menurut Suwatno (2011) mengatakan manajemen adalah perencanaan, pengorganisasian, pengarahan, pengendalian dan pengadaan, pengembangan kompensasi pengintegrasian, pemeliharaan dan pemberhentian pegawai dengan maksud terwujudnya tujuan perusahaan, individu, pegawai dan masyarakat. Berdasarkan beberapa pengertian diatas dapat diketahui bahwa manajemen merupakan suatu proses perencanaan, pengorganisasian, pengarahan dan pengendalian melalui sumber daya manusia untuk mencapai tujuan yang telah ditentukan sebelumnya.

Fungsi-fungsi manajemen menurut Nitisemito (2000) adalah sebagai berikut: (1) perencanaan (Planning) adalah penentuan program personalia yang membantu tercapainya sasaran yang telah disusun; (2) pengorganisasian (Organizing) adalah kegiatan untuk mengorganisaasi semua pegawai dengan menetapkan pembagian kerja, pengaruh kerja, delegasi wewenang, integrasi dan koordinasi dalam bagan perusahaan; (3) pelaksanaan (Actuating) adalah kegiatan yang mungusahakan agar semua perencanaan dan tujuan perusahaan bisa terwujud dengan baik dan seperti yang diharapkan; dan (4) Pengendalian (Controlling) adalah fungsi manajerial yang berpengaruh dengan pengaturan kegiatan agar sesuai dengan rencana personalia yang sebelumnya telah dirumuskan berdasarkan analisis terhadap sasaran dasar organisasi.

\section{Manajemen Sumber Daya Manusia}

Menurut Adisetiawan (2014) Manajemen sumber daya manusia adalah proses mendayagunakan manusia sebagai tenaga kerja secara manusiawi, agar potensi fisik dan psikis yang dimilikinya berfungsi maksimal bagi pencapaian tujuan organisasi (perusahaan). Menurut Sedarmayanti (2009) Manajemen sumber daya manusia adalah seni untuk merencanakan, mengorganisasikan, mengarahkan, mengawasi kegiatan sumber daya manusia atau pegawai dalam rangka mencapai tujuan organisasi. Manajemen Sumber daya Manusia (MSDM) adalah ilmu dan seni mengatur proses pemanfaatan SDM dan sumber-sumber lainnya secara efektif untuk mencapai suatu tujuan tertentu, dimana didalamnya terdapat 6 (enam) unsur, yaitu men, money, methode, material, machines dan market menurut Adisetiawan (2014). Menurut Dessler (2010) MSDM adalah proses memperoleh, melatih, menilai dan memberikan kompensasi kepada karyawan, memerhatikan hubungan kerjanya, kesehatan, keamanan dan masalah keadilan, kebijakan dan praktik menentukan aspek manusia, atau SDM dalam posisi manajemen, termasuk merekrut, menyaring, melatih, memberi penghargaan dan penilaian. 
Fungsi manajemen sumber daya manusia menurut Adisetiawan (2014) menjelaskan secara singkat fungsi-sungsi manajemen sebagai berikut :

1. Perencanaan (planning), Merencanakan tenaga kerja secara efektif dan efisien agar sesuai dengan kebutuhan perusahaan dalam mewujudkan tujuan.

2. Pengorganisasian (organizing), Menyusun suatu organisasi dengan mendesain stuktur dan hubungan antara tugas-tugas yang harus dikerjakan oleh tenaga kerja yang dipersiapkan.

3. Pengarahan (directing), Kegiatan mengarahkan semua karyawan agar mau bekerja sama dan bekerja secara efektif dan efisien dalam membantu tercapainya tujuan perusahaan, karyawan, dan masyarakat.

4. Pengendalian (controlling), Kegiatan mengendalikan semua karyawan agar mentaati peraturanperaturan perusahaan dan bekerja sesuai dengan rencana.

5. Pengadaan tenaga kerja (procurement), Proses penarikan,seleksi, penempatan, orientasi, dan induksi untuk mendapatkan karyawan yang sesuai dengan kebutuhan perusahaan.

6. Pengembangan (development), Proses peningkatan keterampilan teknis, toritis, konseptual, dan moral karyawan melalui pendidikan dan pelatihan.

7. Kompensasi (compensation), Pemberian balas jasa langsung (direct), dan tidak langsung (indirect) uang atau barang kepala karyawan sebagai imbalan jasa yang diberi kepada perusahaan.

8. Pengintegrasian (integration), Kegiatan untuk mempersatukan kepentingan perusahaan dan kebutuhan karyawan, agar tercipta kerja sama yang serasi dan saling menguntungkan.

9. Pemeliharaan (maintenance), Kegiatan untuk memelihara atau meningkatkan kondisi fisik, mental, dan loyalitas karyawan agar mereka mau bekerja sama sampai pensiun.

10. Kedisiplinan (discipline), Keinginan dan kesadaran untuk mentaati peraturan-peraturan perusahaan dan moral-moral sosial.

11. Pemutusan hubungan tenaga kerja (separation), Putusnya hubungan kerja seseorang dari suatu perusahaan. Pemutusan hubungan kerja ini dapat disebabkan oleh keinginan karyawan, keinginan perusahaan, kontrak kerja berakhir, pensiun dan sebab-sebab lainnya.

\section{Karakteristik Individu}

Setiap manusia mempunyai karakteristik individu yang berbeda-beda antara yang satu dengan yang lainnya. Dalam Kamus Besar Bahasa Indonesia (KBBI) yang dimaksud dengan karakteristik adalah ciri atau sifat yang berkemampuan untuk memperbaiki kualitas hidup. Sedangkan individu adalah perorangan atau orang seorang. Menurut Robbins \& Judge (2008) Karakteristik individu merupakan karakteristik seperti usia, gender, ras dan masa kerja (Jabatan) yang diperoleh secara mudah dan objektif dari arsip pribadi seseorang. Menurut Hurriyati (2005) Karakteristik individu merupakan suatu proses psikologi yang mempengaruhi individu dalam memperoleh pengalaman. Karakteristik individu merupakan faktor internal (interpersonal) yang menggerakkan dan mempengaruhi perilaku individu. Sedangkan menurut Mulyadi (2015) Perilaku individu adalah segala tindakan yang dilakukan dalam pekerjaan maupun diluar pekerjaan manusia. Memahami perilaku individu dengan baik, berarti memahami karakteristik yang melekat pada individu.

Menurut Adisetiawan (2013) Karakteristik individu adalah ciri khas yang menunjukkan perbedaan seseorang tentang motivasi, inisiatif, kemampuan untuk tegar menghadapi tugas sampai tuntas atau memecahkan masalah atau bagaimana menyesuaikan perubahan yang terkait erat dengan lingkungan yang mempengaruhi kinerja individu. Adisetiawan (2013), menyatakan bahwa Karakteristik invidu terdiri dari kemampuan, keterampilan, pengalaman, latar belakang individu dan demografi individu yang bersangkutan. Pendapat ahli diatas dapat disimpulkan bahwa karakteristik individu adalah karakter seseorang individu atau ciri-ciri seseorang dalam menggambarkan keadaan individu tersebut yang sebenarnya dan membedakannya dari individu yang lain.

\section{Indikator Karakteristik Individu}

a. Usia, menurut Robbins (2008) menyatakan bahwa semakin tua usia pegawai maka semakin tinggi komitmennya terhadap organisasi, hal ini disebabkan karena kesempatan individu untuk mendapatkan pekerjaan lain menjadi lebih terbatas sejalan dengan meningkatnya usia. Nitisemito (2000) menyatakan bahwa, pegawai yang lebih muda cenderung mempunyai fisik yang kuat, sehingga diharapkan dapat 
bekerja keras dan pada umumnya mereka belum berkeluarga atau bila sudah berkeluarga anaknya relatif sedikit, tetapi karyawan yang lebih muda umumnya kurang disiplin, kurang bertanggung jawab dan sering berpindah-pindah pekerjaan dibandingkan karyawan yang lebih tua. Menurut Robbins (2006) menyatakan usia pegawai yang lebih tua mempunyai tingkat kemangkiran tak terhindarkan lebih dibandingkan dengan pegawai yang lebih muda, mungkin karena kesehatan yang memburuk karena penuaan dan lebih lamanya waktu pemulihaan yang di perlukan pekerja tua bila cidera. Kebanyakan studi juga menunjukkan suatu hubungan yang positif antara kepuasan kerja dengan umur, sekurangnya sampai umur 60 tahun. Kepuasan kerja akan cenderung terus-menerus meningkat pada para pegawau yang profesional dengan bertambahnya umur mereka, sedangkan pada pegawai yang non profesional kepuasan itu merosot selama umur setengah baya dan kemudian naik lagi dalam tahun-tahun berikutnya.

b. Jenis Kelamin (Gender), Manusia dibedakan menurut jenis kelaminnya yaitu pria dan wanita. Robbins (2006) menyatakan bahwa, tidak ada perbedaan yang konsisten antara pria dan wanita dalam kemampuan memecahkan masalah, ketrampilan analisis, dorongan kompetitif, motivasi, sosiabilitas atau kemampuan belajar. Namun studi-studi psikologi telah menemukan bahwa wanita lebih bersedia untuk mematuhi wewenang dan pria lebih agresif dan lebih besar kemungkinannya dari pada wanita dalam memiliki pengharapan untuk sukses. Menurut Mulyadi (2015) Secara fisik wanita dan pria juga berbeda. Karena kodratnya, pegawai wanita lebih sering tidak masuk kerja dibanding pria dikarenakan hamil, melahirkan, dll. Walaupun demikian pegawai wanita memiliki sejumlah kelebihan dibanding pegawai pria. Pegawai wanita cenderung lebih rajin dan sabar. Satu masalah yang tampaknya membedakan antar jenis kelamin, khususnya saat karyawan mempunyai anak-anak pra sekolah, ibu-ibu yang biasanya bekerja full time mungkin akan memilih bekerja dengan paruh waktu jadwal kerja yang lebih fleksibel, dan mengerjakan pekerjaan kantor dirumah agar bisa mengemban tanggung jawab terhadap keluarga. Hal ini disebabkan karyawan wanita merasa bahwa tanggung jawab rumah tangganya ada di tangan suami mereka, sehingga gaji yang diberikan oleh organisasi bukanlah sesuatu yang sangat penting bagi dirinya.

c. Ras, Menurut Robbins \& Timothy (2008) Ras adalah sebuah isu yang kontroversial. Isu ini dapat dengan mudah menimbulkan perdebatan sehingga membuat individu lebih suka menghindari topik ini. Seseorang mendefenisikan ras sebagai warisan biologis yang digunakan individu untuk mengidentifikasi diri mereka sendiri. Defenisi ini memungkinkan setiap individu untuk mendefenisikan rasnya sendiri.

d. Masa Kerja (Jabatan), Robbins (2008) menyatakan bahwa semakin lama seseorang berada dalam suatu pekerjaan, lebih kecil kemungkinannya untuk mengundurkan diri. Masa kerja yang lama akan cenderung membuat seorang pegawai lebih merasa betah dalam suatu organisasi, hal ini disebabkan diantaranya karena telah beradaptasi dengan lingkungannya yang cukup lama sehingga seorang pegawai akan merasa nyaman dengan pekerjaannya. Menurut Robert (2014) faktor lain juga dikarenakan adanya kebijakan dari instansi mengenai jaminan hidup di hari tua.

\section{Motivasi}

Menurut Sedermayanti (2009) Motivasi adalah kondisi mental yang mendorong aktivitas dan memberi energi yang mengarah kepada pencapaian kebutuhan, memberi keputusan atau mengurangi ketidak seimbangan. Menurut Mulyadi (2015) Motivasi adalah dorongan dasar yang menggerakkan seseorang bertingkah laku. Menurut Adisetiawan (2014) bahwa : Motivasi merupakan kondisi jiwa yang mendorong seseorang dalam mencapai prestasinya secara maksimal. Sedangkan menurut Sutrisno (2010) menyebutkan motivasi adalah suatu faktor yang mendorong seseorang untuk melakukan suatu aktivitas tertentu oleh karena itu motivasi sering diartikan pula sebagai faktor pendorong perilaku seseorang.

\section{Indikator Motivasi}

Menurut Sedarmayanti (2009) menyebutkan ada enam indikator motivasi yaitu:

1. Prestasi, Motivasi Pegawai dalam bekerja adalah selalu berusaha untuk terus meningkatkan prestasi dan memiliki tekad untuk mencapai prestasi yang terbaik. 
2. Pengakuan, Pengakuan yang diharapkan pegawai dalam bekerja erat kaitannya dengan mengharapkan adanya penghargaan dari pimpinan, keinginan untuk menunjukkan kemampuan diri serta mengharapkan balas jasa yang sesuai.

3. Kemajuan kenaikan pangkat, Melaksanakan pekerjaan karena keinginan untuk mencapai karir yang lebih baik serta menunjukkan seberapa besar tekad untuk mewujudkannya.

4. Pekerjaan itu sendiri, Pegawai dapat termotivasi bekerja karena pekerjaan itu sendiri dengan keinginan dan harapannya serta sifat pekerjaan yang menantang.

5. Kemungkinan untuk tumbuh, Motivasi seseorang dalam melaksanakan pekerjaan karena adanya keinginan untuk terus mengembangkan diri serta meningkatkan wawasan pegawai.

6. Tanggung jawab, Motivasi seseorang untuk mengerjakan pekerjaan erat kaitannya dengan keinginan mereka untuk melaksanakan tanggung jawab tersebut serta tingkat komitmen untuk melaksanakan pekerjaan.

\section{Hubungan Karakteristik Individu Terhadap Motivasi}

Menurut Robbins \& Judge (2008) Karakteristik individu merupakan karakteristik perseorangan seperti usia, gender, ras dan masa jabatan yang diperoleh secara mudah dan objektif dari arsip pribadi seseorang. Perbedaan karakteristik tersebut akan dibawa kedalam dunia kerja, sehingga dengan adanya perbedaan tersebut menyebabkan motivasi yang berbeda antara satu sama lainnya, walaupun mereka ditempatkan dalam satu lingkungan kerja yang sama. Menurut Mulyadi (2015) Motivasi adalah dorongan dasar yang menggerakkan seseorang bertingkah laku. Sesuatu yang mendorong motivasi di Karakteristik individu adalah kebutuhan materiil, manusia sebagai makhluk yang secara biologis memerlukan kebutuhan materiil untuk mempertahankan kehidupannya. Kebutuhan yang dimaksud berupa : makanan, minuman, gaji, insentif, kendaraan, tunjangan santunan.

\section{Hipotesis}

Adapun hipotesis dalam penelitian ini adalah sebagai berikut:

1. Diduga karakteristik individu baik dan motivasi pegawai Pada Dinas Kesehatan Provinsi Jambi tinggi. .

2. Diduga karakteristik individu berpengaruh terhadap motivasi pegawai pada Dinas Kesehatan Provinsi Jambi.

\section{METODE PENELITAN \\ Jenis dan Sumber Data}

Menurut Syekh (2011) Data dapat diartikan sebagai fakta yang digambarkan lewat angka, simbol, kode dan lain-lain. Dalam penggunaan data dapat diklasifikasikan menjadi dua yakni :

1. Data Primer, Data primer adalah data yang diperoleh atau dikumpulkan langsung dilapangan oleh orang yang melakukan penelitian atau yang bersangkutan memerlukannya. Dalam pengumpulan data primer peneliti mengadakan penelitian secara langsung dan survey kuisioner dengan pegawai pada Dinas Kesehatan Provinsi Jambi.

2. Data Sekunder, Data sekunder adalah data yang diperoleh atau dikumpulkan oleh orang yang melakukan penelitian dari sumber-sumber yang telah ada. Dalam pengumpulan data sekunder, peneliti memperoleh dari studi dokumen untuk mempelajari data-data pada Dinas Kesehatan Provinsi Jambi. Disampimg itu juuga dilengkapi dengan studi atau penelitian kepustakaan (Library research) sebagai data pendukung.

\section{Sumber Data}

Pegawai Dinas Kesehatan Provinsi Jambi yang menjadi responden penelitian, kuisioner ini berbentuk pertanyaan tertutup dimana alternatif jawabannya telah tersedia dari 1-5 skala yang digunakan dalam penelitian ini adalah skala likert.

\section{Metode Pengumpulan Data}

Menurut Istijanto (2009) untuk memperoleh data dan informasi yang diperlukan maka pengumpulan data dan informasi tersebut dilakukan dengan cara sebagai berikut :

1. Penelitian Lapangan (Field Research) 
Penelitian Lapangan yaitu suatu penelitian yang dilakukan melalui penelitian langsung kepada pegawai Dinas Kesehatan Provinsi Jambi, yang berkaitan dengan masalah yang diteliti. Mengumpulkan data secara langsung dengan menggunakan teknik yaitu :

- Wawancara (Interview)

Metode ini merupakan metode pengumpulan data melalui tanya jawab langsung dengan pihak-pihak yang berkepentingan dalam memberikan keterangan dan data-data yang dibutuhkan dalam penelitian.

- Kuesioner

Menurut Sugiyono (2009) kuesioner merupakan teknik pengumpulan data yang dilakukan dengan memberi seperangkat pertanyaan atau pernyataan tertulis kepada responden untuk dijawabnya.

2. Penelitian Kepustakaan (Library Research)

Penelitian Kepustakaan yaitu suatu penelitian kepustakaan dengan jalan mempelajari literatur dan hasilhasil penelitian yang berkaitan dengan masalah yang diteliti.

\section{Populasi dan Sampel}

\section{a. Populasi}

Menurut Sugiyono (2009) populasi adalah wilayah generalisasi yang terdiri dari objek/subjek yang mempunyai kualitas dan karakteristik tertentu yang ditetapkan peneliti untuk dipelajari dan kemudian ditarik kesimpulannya. Menurut Adisetiawan (2013) populasi ialah seluruh kumpulan elemen yang sejenis akan tetapi berbeda karena karakteristiknya Dimana populasi sasaran dalam penelitian ini adalah pegawai Dinas Kesehatan Provinsi Jambi pada tahun 2017 yaitu sebanyak 373 orang pegawai.

b. Sampel

Sampel Menurut Sugiyono (2009) adalah bagian dari jumlah dan karakteristik yang dimiliki oleh populsi tersebut. Bila populasi besar, dan peneliti tidak mungkin mempelajari semua yang ada pada populasi, misalnya karena keterbatasan dana, tenaga dan waktu, maka peneliti dapat menggunakan sampel yang diambil dari populasi itu. Diketahui dari jumlah populasi yang berjumlah 373 pegawai dengan tingkat presisi ditetapkan sebesar 10\%, maka jumlah sampel yang akan diteliti menggunakan pendekatan slovin (Umar, 2013) dengan rumus sebagai berikut:

Keterangan $n=\frac{N}{1+N e^{2}}$

$\mathrm{n}=$ Ukuran sampel

$\mathrm{N}=$ Ukuran populasi

$\mathrm{e}=$ Persentase kelonggaran

Dimana :

$n=\frac{373}{1+373.0,1^{2}}=78,85$ dibulatkan menjadi 79 responden.

\section{Metode Analisis}

Menganalisis permasalahan diatas digunakan skala penelitian dengan menghitung frekuensi skor setiap item pernyataan. Seperti yang dikemukakan Husein (2000) bahwa perhitungan skor setiap komponen yang diteliti dengan mengalikan seluruh frekuensi data dengan bobot. Rumus yang digunakan adalah : Skor terendah $=$ Bobot terendah $\mathrm{x}$ jumlah sampel; Skor tertinggi $=$ Bobot tertinggi $\mathrm{x}$ jumlah sampel; Skor terendah $=1 \times 79=79$; Skor tertinggi $=5 \times 79=395$. Sedangkan untuk mencari rentang skala menurut Rangkuti (2001) digunakan rumus sebagai berikut :

Rentang Skala $=\frac{\mathrm{n}(\mathrm{m}-1)}{\mathrm{m}}$

Dimana : $\mathrm{n}=$ Jumlah sampel; $\mathrm{m} \quad=$ Jumlah alternatif jawaban item

Rentang Skala $=\frac{79(5-1)}{5}=63$

Maka : $79-141=$ Sangat Tidak Baik/Sangat rendah; $142-204=$ Tidak Baik/Rendah; $205-267=$ Cukup Baik/Cukup tinggi; 268 - 330 = Baik/Tinggi; 331 - 395 = Sangat Baik/Sangat tinggi

\section{Alat Analisis \\ Regresi Linear Sederhana}


Uji regresi linear sederhana untuk melihat pengaruh karakteristik individu terhadap motivasi pegawai Dinas Kesehatan Provinsi Jambi digunakan rumus regresi linear sederhana diolah menggunakan alat bantu SPSS 20. Menurut Adisetiawan (2014) rumusnya adalah sebagai berikut : $Y=a+b x+e$

keterangan : $\mathrm{Y}=$ Motivasi Pegawai; $\mathrm{x}=$ Karakteristik Individu; $\mathrm{b}=$ Koofesien Regresi; $\mathrm{a}=$ Nilai Konstanta; $\mathrm{e}=$ tingkat kesalahan (error). Menurut Syekh (2011) cara mendapatkan nilai a dan b dari rumus diatas digunakan rumus sebagai berikut :

$\mathrm{b}=\frac{n \sum x y-\sum x \sum y}{n \sum x^{2}-\left(\sum x\right)^{2}}$

$\mathrm{a}=\frac{\sum y-b \sum x}{n}$

keterangan $: \mathrm{x}=$ variabel indepeden; $\mathrm{y}=$ variabel dependen; $\mathrm{n}=$ jumlah data

\section{Koefisien Determinasi $\left(R^{2}\right)$}

Koefisien determinasi $\left(\mathrm{R}^{2}\right)$ digunakan untuk mengetahui persentase variabel independen secara bersama-sama dapat menjelaskan variabel dependen. Nilai koefisien determinasi adalah di antara nol dan satu. Jika koefisien determinasi $\left(\mathrm{R}^{2}\right)=1$, artinya variabel independen memberikan informasi yang dibutuhkan untuk memprediksi variabel-variabel dependen. Jika koefisien determinasi $\left(\mathrm{R}^{2}\right)=0$, artinya variabel independen tidak mampu menjelaskan pengaruhnya terhadap variabel dependen.

\section{Uji Hipotesis}

Pengujian hipotesis yang digunakan dalam penelitian ini menggunakan uji signifikasi parameter individual (t test) untuk menguji hipotesis penelitian, maka digunakan bantuan software SPSS.

\section{Uji Statistik $t$}

Uji $\mathrm{t}$ digunakan untuk menentukan apakah variabel bebas faktor karakteristik individu (x) berpengaruh terhadap variabel terikat motivasi pegawai (y). Rumus yang digunakan adalah :

1) Rancangan Hipotesis

Ho: tidak ada pengaruh yang signifikan (nyata) antara karakteristik individu terhadap motivasi pegawai. $\mathrm{Hi}$ : ada pengaruh yang signifikan (nyata) antara karakteristik individu terhadap motivasi pegawai.

2) Menghitung t tabel (Sugiyono, 2010) menggunakan ketentuan berikut $: \mathrm{a}=5 \%$

3) Kriteria Keputusan

- Jika thitung > ttabel artinya Ho ditolak Hi diterima terdapat pengaruh antara karakteristik individu terhadap motivasi pegawai.

- Jika thitung < ttabel artinya Ho diterima Hi ditolak tidak dapat pengaruh antara karakteristik individu terhadap motivasi pegawai.

\section{HASIL DAN PEMBAHASAN \\ Pengaruh Karakteristik Individu Terhadap Motivasi Pegawai pada Kantor Dinas Kesehatan Provinsi Jambi}

Pengaruh karakteristik individu terhadap motivasi pegawai pada Kantor Dinas Kesehatan Provinsi Jambi berdasarkan perhitungan SPSS 20 dapat dilihat sebagai berikut :

Tabel 1

Coefficients $^{\mathrm{a}}$

\begin{tabular}{|c|c|c|c|}
\hline \multirow[t]{2}{*}{ Model } & \multicolumn{2}{|c|}{ Unstandardized Coefficients } & Standardized Coefficients \\
\hline & $\mathrm{B}$ & Std. Error & Beta \\
\hline (Constant) & 1.648 & .205 & \\
\hline Karakteristik Individu & .506 & .072 & 623 \\
\hline
\end{tabular}

Sumber: data olahan

Berdasarkan keterangaan tabel 1 diatas diketahui bahwa persamaan regresinya adalah sebagai berikut

$: \mathrm{Y}=\mathrm{a}+\mathrm{bX}+\mathrm{e}$

$\mathrm{Y}=1.648+0.506 \mathrm{X}+\mathrm{e}$ 
Dimana konstanta sebesar 1.648, artinya jika karakteristik individu konstan maka motivasi pegawai pada Kantor Dinas Kesehatan Provinsi Jambi sebesar 1.648. Dan terdapat pengaruh antara karakteristik individu terhadap motivasi pegawai pada Kantor Dinas Kesehatan Provinsi Jambi. Koefisien regresi karakteristik individu sebesar 0.506 artinya jika karakteristik individu mengalami kenaikan 1\% maka motivasi pegawai pada Kantor Dinas Kesehatan Provinsi Jambi akan mengalami peningkatan sebesar 0.506 $\%$

\section{Uji Hipotesis $t$}

Uji t digunakan untuk melihat pengaruh antara karakteristik individu $(\mathrm{X})$ terhadap motivasi pegawai (Y) dengan kriteria sebagai berikut :

\section{Tabel 2}

Uji t

\begin{tabular}{|ll|r|r|r|r|}
\hline \multirow{2}{*}{ Model } & \multicolumn{2}{|c|}{ Unstandardized Coefficients } & \multirow{2}{*}{ S } & \multirow{2}{*}{ Sig. } \\
\cline { 3 - 6 } & (Constant) & B & Std. Error & & \\
\hline \multirow{2}{*}{1} & & 1.648 & .205 & 8.045 & .000 \\
& Karakteristik Individu & .506 & .072 & 6.992 & .000 \\
\hline
\end{tabular}

Sumber: data olahan

Dengan menggunakan $a$ 0,05 dengan ketentuan $\mathrm{df}=\mathrm{n}-\mathrm{k}-1$ atau 79-1-1 $=77$. Maka pengaruh karakteristik individu terhadap motivasi pegawai pada Kantor Dinas Kesehatan Provinsi Jambi berdasarkan hasil perhitungan diperoleh angka thitung 6.992 sedangkan $t_{\text {tabel }}$ sebesar 1.991. Jadi thitung $6.992>1.991$ dengan tingkat signifikan 0.000, maka keputusannya $\mathrm{H}_{\mathrm{o}}$ ditolak dan $\mathrm{H}_{\mathrm{i}}$ diterima. Hal ini berarti karakteristik individu berpengaruh signifikan terhadap motivasi pegawai pada Kantor Dinas Kesehatan Provinsi Jambi.

\section{Koefisien Determinasi $\left(R^{2}\right)$} berikut :

Hasil perhitungan SPSS untuk koefisien determinasi dapat dilihat pada model summary sebagai

Tabel 3

Koefisien Determinasi

\begin{tabular}{|l|r|r|r|r|}
\hline Model & R & \multicolumn{1}{|c|}{ R Square } & Adjusted R Square & \multicolumn{1}{c|}{ Std. Error of the Estimate } \\
\hline 1 & $.623^{\mathrm{a}}$ & .388 & .380 & .22160 \\
\hline
\end{tabular}

Sumber: data olahan

Berdasarkan hasil perhitungan pada tabel diatas dapat dilihat bahwa terdapat hubungan keeratan antara karakteristik individu terhadap motivasi pegawai sebesar 0,388. Dari hasil pengujian hipotesis maka diperoleh nilai $\mathrm{R}$ Square sebesar 0.388 , angka ini menyatakan variabel karakteristik individu (X) mampu menjelaskan variabel motivasi kerja (Y) sebesar 38.8\% pada Kantor Dinas Kesehatan Provinsi Jambi.

\section{Analisis Karakteristik Individu pada kantor Dinas Kesehatan Provinsi Jambi Analisis Motivasi pada kantor Dinas Kesehatan Provinsi Jambi}

Berdasarkan hasil rekap tanggapan kuesioner terhadap 13 item motivasi pada Dinas Kesehatan Provinsi Jambi, diketahui skor tertinggi ada pada indikator tanggung jawab, total skor sebesar 345, artinya responden setuju jika penerapan tanggung jawab ditempat kerja harus berimbang. Sedangkan skor jawaban terendah ada pada indikator pekerjaan itu sendiri, total skornya sebesar 306. Artinya motivasi di instansi yang dilaksanakan oleh pimpinan selama ini belum berjalan maksimal.

\section{Analisis Pengaruh Karakteristik Individu Terhadap Motivasi Pegawai Pada Dinas Kesehatan Provinsi Jambi}

Hasil perhitungan persamaan regresi linear sederhana, analisis regresi mempelajari pengaruh yang diperoleh yang dinyatakan dalam persamaan sebagai berikut :

$\mathrm{Y}=1.648+0.506 \mathrm{X}+\mathrm{e}$ 
Persamaan ini menunjukkan bahwa koefisien regresi karakteristik individu mempunyai arah yang positif terhadap motivasi pada Dinas Kesehatan Provinsi Jambi. Koefisien regresi karakteristik individu (X) sebesar 0,506 artinya jika karakteristik individu (X) mengalami peningkatan 1\% maka motivasi (Y) pegawai Dinas Kesehatan Provinsi Jambi mengalami kenaikan sebesar 0,506. Koefisien determinasi diketahui dari nilai $\mathrm{R}^{2} 0,388(38,80 \%)$ yang artinya karakteristik individu mampu menjelaskan motivasi (Y) pada Dinas Kesehatan Provinsi Jambi sebesar 38,80\% dan sisanya dipengaruhi oleh faktor lainnya yang tidak diteliti.

\section{SIMPULAN}

Berdasarkan pembahasan pada pembahasan sebelumnya maka dapat ditarik beberapa kesimpulan sebagai berikut :

1. Karakteristik individu baik dan motivasi pegawai pada Kantor Dinas Kesehatan Provinsi Jambi tinggi.

2. Karakteristik individu berpengaruh signifikan terhadap motivasi pegawai artinya apabila karakteristik individu baik, maka motivasi pegawai Kantor Dinas Kesehatan Provinsi Jambi meningkat.

\section{DAFTAR PUSTAKA}

Adisetiawan, R., 2014, Performance Mahasiswa Fakultas Ekonomi Universitas Batanghari, Jurnal Ilmiah Universitas Batanghari Jambi, 14(3), 1-10

Adisetiawan, R., 2013, Kajian Persepsi Pemilik Usaha Kecil dan Menengah (UKM) Terhadap Laporan Keuangan, Jurnal Ilmiah Universitas Batanghari Jambi, 13(4), 162-173

Alhudhori, M., 2018, Pengaruh Pelatihan Terhadap Kinerja Pegawai pada Puskesmas Simpang Kawat Kota Jambi, Jurnal Ilmiah Universitas Batanghari Jambi, 18(3), 654-858

Istijanto, 2009. Aplikasi Riset. PT. Gramedia Pustaka Utama, Jakarta.

Mulyadi, Deddy. 2015 Perilaku Organisasi dan Kepemimpinan Pelayanan. Alfabeta, Bandung.

Nitisemito, Alek. S. 2000. Manajemen Personalia. Ghalia Indonesia. Bogor.

Rangkuti, Freddy. 2001. Pengantar Statistik. Penerbit Gramedia, Jakarta.

Kreitner, Robert \& Kinicki, Angelo. 2014. Perilaku Organisasi. Salemba empat, Jakarta.

Robbins, Stephen P. dan Timothy A. Judge. 2008. Perilaku Organisasi. Salemba Empat, Jakarta.

Sedarmayanti 2009. Sumber Daya Manusia dan Produktivitas Kerja. CV. Mandar Maju, Bandung.

Sugiyono, 2009. Metode Penelitian Kuantitatif Kualitatif Dan R \& D. Bandung: Alfa Beta.

Sugiyono, 2010. Metode Penelitian Bisnis. Alfabeta, Bandung.

Sutrisno, 2010. Manajemen Sumber Daya Manusia. Kencana Prenada Media Group, Jakarta

Suwatno, 2011. Asas-asas Manajemen Sumber Daya Manusia. Suci Press, Bandung.

Syekh, Sayid. 2011. Pengantar Statistik Ekonomi dan Sosial. Gunung Persada Perss, Jakarta.

Umar, H., 2013. Desain Penelitian MSDM dan perilaku karyawan. Rajawali Pers, Jakarta.

Robbins, 2006. Artikel Karakteristik Individu 